\title{
Diversity of Organic Produce in Indonesia
}

\author{
Nyoman Oka Tridjaja \\ Community Concern Organic Farmer (CCOF), Horticulture Bld, Jalan AUP no. 3, Pasar Minggu, Jakarta 12520, Indonesia
}

\begin{abstract}
Organic farming in Indonesia has been developed quite pass in the last five years. This evidence was pushed by increasing the demand either in domestic or in foreign market. The increase of demand was due to the icrease of awareness of society to healthy and savety food for people. Related to this isues the Government of Indonesia has built an Organic Farming Competence Authority (OKPO). This Competent has responsibilities to facilitate and administrate organic farming business in Indonesia. The diversity of organic produced in Indonesia is mostly paddy/rice, and followed by other organic products such as nutmeg, cashew nut, cinnamon, capsicum, mangosteen, brown sugar or other coconut products, cocoa bean, coffee bean, clover, pepper, Zalacca, lychee, longan, duku (lanseh) and some fruits and vegetables. Mostly organic produce is exported to foreign coutries. There are also some assosiations such as Indonesia Organic Aliance (AOI), Indonesia Farmer Organic Assosiation (APOI), Community Concern Organic Farmer (CCOF) who support the development of organic movement. Certification Body for Competency of Inspectors and Facilitators for organic divelopment either for plant or livestock has just been established.
\end{abstract}

Key words: Organic farming, certification, Organic Farming Competence Authority (OKPO), Organic Certification Body (LSO), organic produce, diversity.

\section{Introduction}

Organic farming is a form of agriculture which avoids or largely excludes the use of synthetic fertilizers and pesticides, plant growth regulators, and livestock feed additives. As far as possible, organic farmers rely on crop rotation, integrated pest management, crop residues, animal manures and mechanical cultivation to maintain soil productivity and till to supply plant nutrients, and to control weeds, insects and other pests. For animals, it means that they were reared without the routine use of antibiotics and without the use of growth hormones [1]. In most countries, organic produce must not be genetically modified. Organic farming is now gaining popularity and is being accepted by people all over the world. A growing consumer market is naturally one of the main factors encouraging farmers to convert to organic agricultural production. Increased consumer awareness of food safety issues and environmental concerns has contributed to the growth in organic farming over the last few years. Historically, organic

Corresponding Author: Nyoman Oka Tridjaja, director, research fields: postharvest and sustainable commodities. farms have been relatively run by small farmer, which is why organic food have been once only available in small stores or farmers' markets [2]. Now, organic foods are becoming much more widely available.

Intering the 21st Century, there emerged the "back to nature" lifestyle where people became more aware of the negative impact of chemo-synthetic inputs. Therefore, organic farming became one of the alternatives to the new lifestyle. The consumer preference to organic products had increased its demand and consequently, organic farming continued to develop in the country [3].

Majority of Indonesia farmers are small farmer with large of cultivation area less than 0.25 ha each and lack of technology information access and net working [4]. Based on these situation and condition the consumers demand for safety and healthy product and its concern to sustainable environment (eco-labelling attributes) has become a basic rationale to the Government of Indonesia to develop organic farming system and use it as an alternate agriculture to increase food production and food savety. Most of Indonesia's organic farming products are fresh 
products [4]. However, resently organic produce has been developed to perinial crops such as coconut product, coffee bean, cocoa bean, nutmeg, clover, cashew nut, honey, etc. Based on this condition, some of these products have received certificate from organic Certification Body in Indonesia and some from International Certification Body. To gain benefits from organic farming, some eforts need to be conducted, such as: building the important of organic farming awareness, capacity building, and increasing in all aspect of production and post harvest, preparing and strengthening infrastructure and supporting units.

The developing and strengthening organic farming networking is a big activity, a solid cooperation among farmers as producers, academician, consumers, Government, media, NGO's and international organization such as IFOAM, and Codex should be a necessity. This paper aims to explain organic farming development and diversity of organic products in Indonesia including the rule of Government as Competent Authority for Organic farming, and diversity of organic products have been achieved. An approache for the development and extension of organic farming to give an overview of the process of organic farming development in Indonesia and their products has being made. Marketing of organic produce and its traceability of product is also an important isue in Indonesia [5].

\section{The History of Indonesia Organic Development}

The first organic farming movement in Indonesia started in 1984 through the establishment of Bina Sarana Bakti (BSB) Foundation as the center for organic agriculture development by Rev. Agatho Elsener Organic Farming Training Center in Indonesia that has trained more than 10,000 farmers and organizations all over the country such as the Integrated Pest Management (IPM) program which was largely conducted, especially in rice farming [6]. This program had decreased the use of pesticide up to
90\% (1985 to 1990). In 1990, the first network of farmer and fishery group, SPTN-HPS, was founded in Jogjakarta. Afterwards, the first Indonesian Organic Agriculture Network (JAKERPO) was established in 1998 by Biotani-PAN Indonesia, SPTN-HPS, Konphalindo, PPLH Seloliman and Gita Pertiwi during Organic Agriculture Workshop supported by International Federation for Organic Agriculture Movements (IFOAM). The network focuses on technical support for farmers and local marketing. In 1999, the first local direct selling of organic products, especially rice, was introduced by Sahani cooperative in Jogjakarta.

The history of organic movement in Indonesia was based on increasing the awareness on improvement of natural conditions where the nature has been explored abnormal, so that destroy the nature, pollute the water resources, deforestation, increasing gas emision in the air, global warming etc. Base on these isues, the aims to go back to the nature are: (1) Employing long-term, ecological, systems-based organic management; (2) Assuring long-term, biologically-based soil fertility; (3) Avoiding/minimizing synthetic inputs at all stages of the organic product chain and exposure of people, and the environment to persistent, potentially harmful chemicals; (4) Minimizing pollution and degradation of the production/processing unit and surrounding environment from production/processing activities; (5) Excluding certain unproven, unnatural and harmful technologies from the system; (6) Avoiding pollution from surrounding environment; (7) Maintaining organic integrity throughout the supply chain; and (8) Providing organic identity in the supply chain.

\section{Current Situation}

\subsection{Development of Organic Farming in Indonesia}

A new society of Community Concern Organic Farmer (CCOF) was established in 2000 by persons who concern to smallholders organic farmer whom is not able to pay for certification. This society will help to guarantee their organic products after CCOF 
conducted verification of their land history, source of water, use of agro-input and the proces of farming system. When those things done acording to Indonesia Organic Standard SNI No. 01-6729-2013 that means CCOF will be able to make guarantee on it.

“Go Organic 2010" and Organic Products Festival 2010 were conducted in Bali to support Bali Organic Island Movement (BOIM) as yearly program which was initiated by the Ministry of Agriculture and the activist of Indonesian Organic Alliance (AOI). It consisted of 45 organization members all over the country. BIOcert is the first national certification body, was developed by AOI. In 2003, Indonesian Organic Producer Association (APOI) was established by organic farmers to improve the quality of product and their farm.

In Indonesia over the last few years, many farmers converted their lands for organic agricultural production [3]. This phenomenon was related to public awareness on food safety. The society considered that the use of synthetic chemicals can make damage to the eco-system and human health. The healthy lifestyle with motto "back to nature" has become world society new trend. The government of Indonesia has concerned to this issue, a big interest of organic farming must be balanced with the government distinct regulation. In order to develop organic farming sustain, the Government of Indonesia has built an Organic Farming Competence Authority (OKPO). This Competence Authority is under coordination of Directorate General of Processing and Marketing for Agricultural Product, Ministry of Agriculture.

The responsibility of OKPO among others is to facilitate and to administrate organic farming in Indonesia. OKPO has set several programs to be completed e.g.: (1) development of Standard, Guideline and Technical Regulation of Organic Farming; (2) preparation and improvement of infrastructure and supporting units, such as Organic Certification Body (LSO); (3) conduct of socialization and national campaign of organic products in mass media and electronic; (4) increase of competency of organic stake holder, such as farmers, traders, organic outlets, certification bodies, academicians, research, laboratory and extension services; (5) facilitation of market access; (6) established of certification system; (7) facilitation on develop and research as references for Organic Certification Body; (8) organic farming supervision activities.

The Government of Indonesia has formulated the National Standard on Organic Food System [1]. This standard was adapted from the Codex Alimentarius Standard CAC GL/32-1999, Rev. I-2001, Guide lines for the Production, Processing, Labeling, and Marketing of Organically Produced Foods. The standard is used as a reference for organic stake holders. The purposes of this standard are : (a) to protect consumer from market manipulation and imitation products; (b) to protect producer and organic product from agricultural product deception; (c) to extend guarantee that all of the production phase, handling, storage, transportation and marketing can be inspected and appropriate with the requirements of standard. The aims of the standars are: (a) to harmonize production system, certification, identification, and labeling of organic product; (b) to prepare organic food standard which is acknowledgment in national and international for export purpose; (c) to maintain and develop organic farming system in Indonesia. This standard contents the principles of organic production, beginning from cultivation activity, storage, transportation, labeling and marketing.

Organic certification is a certification process for producers of organic food and other organic agricultural produce. Organic certification intended to assure quality and prevent fraud [3]. While such certification was not necessary in the early days of the organic movement, when small farmers would sale their produce directly at farmers' markets, as organics have grown in popularity, more and more consumers are purchasing organic food through traditional channels, such as supermarkets [5]. As such, 
consumers are divorced from the growers, and so must rely on third party regulatory certification. For organic producers, certification identifies suppliers of products approved for use in certified operations. For consumers, "certified organic" serves as a product assurance. To get an approbation and legal certificate, the certification process should be conducted by the accredited certification body [3]. The Government of Indonesia has formulated a National Accreditation Committee (KAN) Guidelines No. 901; 2002 as the reference guidance for the Organic Certification Bodies (LSO). This Guideline is combination between IFOAM standard and National Standardization Agency Guidelines No. 401.

\subsection{Certification Procedure}

To get an organic certificate, Certification Body (LSO) must be complied to this requirement bellow [4]:

(1) Documentation System Requirements

a. Management Requirements, such as: Quality Policy, Organization, Personnel, Document Control, Purchasing, Complaint, Incorrect Product, Control, Correction Action, Prevention Action, Record Control, Internal Audit, System Review, Amendment;

b. Technical Requirements: Crop Cultivation, Animal Husbandry Cultivation, Processing, Storage, Handling and Transportation of Organic Farming Products, Labeling and Market Information.

(2) Certification Process

a. Application;

b. Application review;

c. Field Inspection, Scheduling, Information and Verification, and Field Interview.

(3) Inspected Operation Document

a. Certificate issue;

b. Certificate rejection;

c. Certificate extension.

\section{The Future of Organic Indonesia}

The Government policy has been setted to develop, facilitate, and manage organic farming. There were programs which were focused on: technical supports and certification, market promotion, trade and industrial development, organic standard recognition, harmonization and cooperation, expanded market access, and strengthening of organic farmer organization.

To show the commitment of the Government of Indonesia on organic development, in year 2007 has allocated some US\$ 3.23 million to support this programe. The funds were used to support the development of organic pilot projects, feasibility studies, agro input developments, organic cultivation techniques, post harvest activities, organic certification and also financial support on training for organic farmers (smallholders).

In year 2008, the development of organic farming mainly was focused on national and international cooperation [4]. The cooperation needs to be conducted such as: (1) Facilitating exports by training of producers and providing participation of operators and traders in European Organic Fair (Biofach), China Organic Fair and Korea; (2) Training of Farmer Coperatives on implementation of an Internal Control System (ICS); (3) Financial business services for small and medium enterprises (SMEs); (4) Training of instructors, technicians, NGOs, multipliers; (5) Training for advanced inspector; (6) Strengthening staff's capabilities of Competent Authority; (7) Technical support for acceptance of Indonesian certification system by EU to achieve a mutual recognition agreement; (8) Supporting Indonesia certification bodies in networking on international level (national and international co-operations in regard to training, standard setting, accreditation).

\section{Conclusion}

Entering 21st century, healthy lifestyle with motto "back to nature" has become a world society new trend. The society considered that the use of synthetic chemicals can damage the eco-system and human 
health. The developed countries are concerned to this issue by arranging a global trade regulation which required, so that agricultural products must be safety to consume. The consumers demand for safety and healthy product and the concern to sustainable lifelyhood has become a basic rationale to the Governmnet of Indonesia to develop organic farming system and use it as an alternate agriculture to increase.

The diversity of organic farming products is mostly fresh product, however, there are some procesed products. Currently, the well known Indonesia's organic products are coffee bean, cashew nut, honey, vanilla, nutmeg, cocoa bean, spices (ginger, tumeric, wild ginger, curcurma sp, and other medicinal plants etc.) as raw materials for Indonesia healthy drink (Jamu) which produce at wild harvested area, and horticulture products such as Zalaccas, mangoes, mangoesteen, durians, coconut (brown sugar), some vegetables such as cabage, salada, kangkung, brocolli etc., Cereal products such as red rice, local Borneo rice, aromatic rice, local gelatinous rice, shorgum etc. In order to develop organic farming sistem, the Government of Indonesia has built an Organic
Farming Competence Authority (OKPO). This Competence Authority is responsible for controlling fresh organic products inspection through, and for procesed organic product inspected by Food and Drug Inpection Agency either imported or exported organic products.

\section{References}

[1] SNI 01-6729-2013. Organic Farming System, National Standardization Agencies (BSN), Jakarta.

[2] Sumner, J. 2005. Organic Farmers and Rural Development. A Research Report on the Links between Organic Farmers and Community Sustainability in Southwestern Ontario.

[3] The Guidelines for Certification of Organic Farming, 2005. Directorate General of Processing and Marketing for Agricultural Product, Ministry of Agriculture, Jakarta. ing for Agricultural Product, Ministry of Agriculture.

[4] Suleman, D. 2007. The Development of Organic Farming in Indonesia, Directorate General of Processing and Market.

[5] Sulaeman, A. 2007. "Prospek Pasar dan Kiat Pemasaran Produk Pangan Organik.” Seminar Nasional Pertanian Organik, Desember 4, 2007. IPB, Bogor, Indonesia.

[6] Surono, J. I. 2007. “Country Case Study of Indonesia.” In Regional Conference on Organic Agriculture, Asia, December 12-15, 2007, Bangkok, Thailand. 